\title{
PENGARUH PENGGUNAAN LIMBAH BETON TERHADAP PARAMETER MARSHALL CAMPURAN BERASPAL BERPORI
}

\author{
Rista Siang \\ Fakultas Teknik dan Ilmu Komputer \\ Universitas Kristen Krida Wacana \\ Jln. Tanjung Duren Raya No. 4 \\ Jakarta Barat \\ Rista.siang@gmail.com
}

\author{
Amelia Makmur \\ Fakultas Teknik dan Ilmu Komputer \\ Universitas Kristen Krida Wacana \\ Jln. Tanjung Duren Raya No. 4 \\ Jakarta Barat \\ Ameliamakmur@gmail.com
}

\begin{abstract}
A problem that may occur in road pavements that are relatively impermeable to water is the runoff of water, because water cannot seep to the bottom of the pavement, so it can be drained into a drainage system. To overcome this problem, a porous asphalt mixture can be used. In this study the use of concrete waste was tried to replace the coarse aggregate used to make porous asphalt mixtures. For this reason, experiments are carried out in the laboratory, by making some specimens, which are then subject to Marshall testing. The coarse aggregate used to make the mixture is replaced by concrete waste, with a proportion of $25 \%, 50 \%, 75 \%$, and $100 \%$. The results of this study indicate that concrete waste changes the Marshall parameters of a porous asphalt mixture.
\end{abstract}

Keywords: porous asphalt mixture; Marshall testing; concrete waste; Marshall parameter.

\begin{abstract}
Abstrak
Suatu permasalahan yang mungkin terjadi pada perkerasan jalan yang relatif kedap air adalah adanya limpasan air, karena air tidak dapat meresap hingga ke bawah perkerasan, untuk dapat dialirkan ke suatu sistem drainase. Untuk mengatasi masalah tersebut, dapat digunakan campuran beraspal berpori. Pada studi ini dicoba penggunaan limbah beton untuk mengganti agregat kasar yang digunakan untuk membuat campuran beraspal berpori. Untuk itu dilakukan percobaan di laboratorium, dengan membuat benda-benda uji, yang selanjutnya dilakukan pengujian Marshall. Agregat kasar yang digunakan untuk membuat campuran diganti dengan limbah beton, dengan proporsi sebesar 25\%, 50\%, 75\%, dan 100\%. Hasil penelitian ini menunjukkan bahwa limbah beton mengubah parameter Marshall campuran beraspal berpori.
\end{abstract}

Kata-kata kunci: campuran beraspal berpori; pengujian Marshall; limbah beton; parameter Marshall.

\section{PENDAHULUAN}

Salah satu penyebab kerusakan jalan adalah pengaruh genangan air pada lapisan perkerasan. Hal ini disebabkan karena kedapnya lapisan perkerasan, sehingga tidak mampu meloloskan air sampai ke lapisan di bawah perkerasan, untuk kemudian dialirkan ke suatu sistem drainase. Suatu alternatif untuk mengurangi dampak adanya genangan air tersebut tersebut adalah dengan menggunakan lapis perkerasan berpori.

Campuran perkerasan beraspal berpori menggunakan agregat kasar dengan komposisi yang lebih banyak dibandingkan dengan agregat halus. Dalam penggunaannya, perkerasan beraspal berpori ini memiliki nilai stabilitas yang lebih rendah, sehingga diperlukan suatu upaya yang dapat meningkatkan kinerja stabilitas perkerasan beraspal berpori tersebut. 
Suatu alternatif yang dapat digunakan adalah dengan memanfaatkan limbah beton. Penelitian ini bertujuan untuk mengetahui pengaruh penggunaan limbah beton, sebagai bahan substitusi agregat kasar, terhadap Parameter Marshall pada campuran beraspal berpori. Hasil penelitian ini diharapkan dapat menjadi suatu alternatif penggunaan limbah beton sebagai pengganti agregat dan menghasilkan suatu campuran beraspal berpori yang dapat diaplikasikan.

Campuran beraspal berpori atau porous asphalt adalah suatu campuran beraspal yang memiliki rongga atau pori dengan ukuran yang lebih besar dibandingkan dengan campuran beton aspal pada umumnya. Campuran beraspal berpori ini merupakan campuran beraspal yang didesain untuk mempunyai kadar pori yang lebih tinggi, karena menggunakan agregat kasar yang lebih banyak dibandingkan dengan beton aspal yang biasa dijumpai. Kandungan pori pada campuran beraspal berpori tersebut diharapkan juga menghasilkan kondisi permukaan yang kasar sehingga memiliki tingkat kekasatan yang tinggi (Djumari dan Sarwono, 2009).

Limbah beton merupakan limbah padat yang tidak dapat diangkut oleh air dan tidak dapat digunakan lagi. Limbah beton biasanya dihasilkan dari sisa-sisa atau dari reruntuhan bangunan tua, bongkaran bangunan, kegagalan dalam produk beton pracetak, sisa pengujian dari laboratorium, konsumsi berlebihan dari sumber daya, kerusakan material, rework, dan sebagainya.

Dampak limbah konstruksi sangat besar pengaruhnya terhadap lingkungan. Salah satu contoh limba konstruksi ini adalah polusi bahan kimia, yang disebabkan oleh pelepasan partikel-partikel ke udara akibat produksi atau pengangkutan material-material sisa, seperti semen, yang dibuang secara sembarangan (Ramachandran et al., 2002).

Dalam penggunaannya, limbah beton memiliki kelebihan dan kekurangan. Material limbah beton, yaitu agregat, semen, dan air yang dicampur sehingga membentuk batuan yang kaku dan keras. Limbah beton memiliki tingkat kekokohan dan kuat tekan yang tinggi. Dari sifat tersebut, limbah beton dapat memberikan keuntungan apabila digunakan sebagai agregat untuk menggantikan agregat alami pada campuran beraspal berpori. Di sisi lain, limbah beton memiliki kekurangan, yang mana limbah beton memiliki kuat tarik yang rendah, sehingga dalam penggunaannya limbah beton dapat menyebabkan terjadinya retak (Wagih et al., 2013).

Metode yang dilakukan pada penelitian ini adalah metode eksperimental, yaitu melakukan percobaan secara langsung di laboratorium. Untuk itu dibuat campuran beraspal berpori, dengan kadar limbah beton yang digunakan adalah 25\%, 50\%, 75\%, dan 100\% terhadap agregat kasar yang ada dalam campuran.

Campuran beraspal berpori yang digunakan pada studi ini merupakan campuran beraspal yang memenuhi spesifikasi untuk lapisan aus. Komposisi agregat dan aspal untuk membuat campuran pada penelitian ini mengikuti komposisi yang digunakan untuk membuat campuran beraspal berpori untuk lapisan aus, yang telah dilakukan oleh Djumari dan Sarwono (2009). 


\section{HASIL DAN ANALISIS}

Benda-benda uji campuran beraspal berpori dibuat dengan menggunakan data hasil pengujian material aspal dan agregat. Hasil pengujian material aspal, agregat, dan limbah beton disajikan pada Tabel 1 hingga Tabel 3. Aspal yang digunakan adalah aspal minyak Pen. 60/70. Pada Tabel 1 disajikan hasil pengujian aspal yang digunakan pada studi ini, yaitu penetrasi, berat jenis, penyelimutan, daktilitas, serta titik nyala, dan titik bakar.

Tabel 1 Hasil Pengujian Aspal

\begin{tabular}{cllcll}
\hline No. & Karakteristik & $\begin{array}{c}\text { Standar } \\
\text { Pengujian }\end{array}$ & Hasil & Spesifikasi & Keterangan \\
\hline 1 & Penetrasi & SNI 2456:2011 & 66,8 & Tipe 60/70 & Memenuhi \\
2 & Berat Jenis & SNI 2441:2011 & 1,032 & Min. 1,0 & Memenuhi \\
3 & Penyelimutan & SNI 3645:2011 & $99 \%$ & Min. 95\% & Memenuhi \\
4 & Daktilitas & SNI 2432:2011 & $>100$ & Min. 100 cm & Memenuhi \\
5 & Titik Nyala dan & SNI 2433:2011 & 338 & Min. 232 & Memenuhi \\
& Titik Bakar & & 342 & & \\
\hline
\end{tabular}

Tabel 2 Hasil Pengujian Agregat

\begin{tabular}{|c|c|c|c|c|}
\hline Karakteristik & $\begin{array}{c}\text { Standar } \\
\text { Pengujian }\end{array}$ & Spesifikasi & Hasil & Keterangan \\
\hline \multicolumn{5}{|l|}{ A. Agregat Kasar } \\
\hline Berat Jenis Bulk & SNI 1969:2008 & Min. $2,4 \mathrm{gr} / \mathrm{cm}^{3}$ & $2,59 \mathrm{gr} / \mathrm{cm}^{3}$ & Memenuhi \\
\hline Berat Jenis SSD & SNI 1969:2008 & Min. $2,4 \mathrm{gr} / \mathrm{cm}^{3}$ & $2,63 \mathrm{gr} / \mathrm{cm}^{3}$ & Memenuhi \\
\hline Berat Jenis Semu & SNI 1969:2008 & Min. $2,4 \mathrm{gr} / \mathrm{cm}^{3}$ & $2,68 \mathrm{gr} / \mathrm{cm}^{3}$ & Memenuhi \\
\hline Penyerapan & SNI 1969:2008 & Maks. $3 \%$ & $1,29 \%$ & Memenuhi \\
\hline Keausan Agregat & SNI 03-2517-1991 & Maks. $30 \%$ & & \\
\hline Kadar Lumpur & PBI 1971 & Maks. $1 \%$ & & \\
\hline \multicolumn{5}{|l|}{ B. Agregat Halus } \\
\hline Berat Jenis Bulk & SNI 1970:2008 & $1,6-3,2 \mathrm{gr} / \mathrm{cm}^{3}$ & $2,55 \mathrm{gr} / \mathrm{cm}^{3}$ & Memenuhi \\
\hline Berat Jenis SSD & SNI 1970:2008 & $1,6-3,2 \mathrm{gr} / \mathrm{cm}^{3}$ & $2,60 \mathrm{gr} / \mathrm{cm}^{3}$ & Memenuhi \\
\hline Berat Jenis Semu & SNI 1970:2008 & $1,6-3,2 \mathrm{gr} / \mathrm{cm}^{3}$ & $2,68 \mathrm{gr} / \mathrm{cm}^{3}$ & Memenuhi \\
\hline Penyerapan & SNI 1970:2008 & Maks. 3\% & $1,85 \%$ & Memenuhi \\
\hline
\end{tabular}

Tabel 3 Hasil Pengujian Limbah Beton

\begin{tabular}{clcccc}
\hline No. & Karakteristik & $\begin{array}{c}\text { Hasil } \\
\text { Pengujian }\end{array}$ & $\begin{array}{c}\text { Standar } \\
\text { Pengujian }\end{array}$ & Persyaratan & Keterangan \\
\hline 1 & Berat Jenis Bulk & $2,47 \mathrm{gr} / \mathrm{cm}^{3}$ & SNI 1969: 2008 & Min 2,4 gr/cm & Memenuhi \\
2 & Berat Jenis SSD & $2,53 \mathrm{gr} / \mathrm{cm}^{3}$ & SNI 1969: 2008 & Min 2,4 gr/cm & Memenuhi \\
3 & Berat Jenis Semu & $2,64 \mathrm{gr} / \mathrm{cm}^{3}$ & SNI 1969: 2008 & Min 2,4 gr/cm & Memenuhi \\
4 & Penyerapan Air & $2,63 \mathrm{gr} / \mathrm{cm}^{3}$ & SNI 1969: 2008 & Maks 3\% & Memenuhi \\
5 & Abrasi Los Angeles & $29,12 \mathrm{gr} / \mathrm{cm}^{3}$ & SNI 03-2517-1991 & Maks 40\% & Memenuhi \\
\hline
\end{tabular}

Pada Tabel 2 dan Tabel 3 disajikan hasil-hasil pengujian terhadap agregat dan limbah beton. Semua pengujian dilakukan sesuai dengan Standar Nasional Indonesia (SNI). Hasil yang diperoleh menunjukkan bahwa limbah beton yang digunakan pada studi ini memenuhi spesifikasi yang disyaratkan.

Pada Tabel 4 ditunjukkan hasil pengujian terhadap benda-benda uji Marshall yang dibuat dengan menggunakan Kadar Aspal Optimum (KAO) dan dengan menggunakan limbah 
beton dengan berbagai kadar kadar limbah beton. Parameter Marshall yang diperoleh tersebut kemudian dibandingkan dengan nilai parameter Marshall yang didapat dari benda-benda uji yang menggunakan kadar aspal optimum tanpa limbah beton. Besarnya pengaruh penggunaan limbah beton dinyatakan dalam persen. Hasil perbandingan tersebut dapat dilihat pada Gambar 1 hingga Gambar 5.

Tabel 4 Hasil Pengujian Campuran Beraspal Berpori Menggunakan Limbah Beton

\begin{tabular}{cccccc}
\hline $\begin{array}{c}\text { Kadar Limbah } \\
\text { Beton }\end{array}$ & $\begin{array}{c}\text { VIM } \\
(\%)\end{array}$ & $\begin{array}{c}\text { VMA } \\
(\%)\end{array}$ & $\begin{array}{c}\text { Stability } \\
(\mathrm{kg})\end{array}$ & $\begin{array}{c}\text { Flow } \\
(\mathrm{mm})\end{array}$ & $\begin{array}{c}\text { MQ } \\
(\mathrm{kg} / \mathrm{mm})\end{array}$ \\
\hline $25 \%$ & 20,32 & 17,75 & 580,933 & 5,30 & 109,61 \\
$50 \%$ & 18,85 & 18,02 & 840,000 & 5,60 & 150,00 \\
$75 \%$ & 23,95 & 23,57 & 707,588 & 5,43 & 130,23 \\
$100 \%$ & 20,58 & 20,18 & 627,255 & 4,33 & 144,75 \\
\hline
\end{tabular}

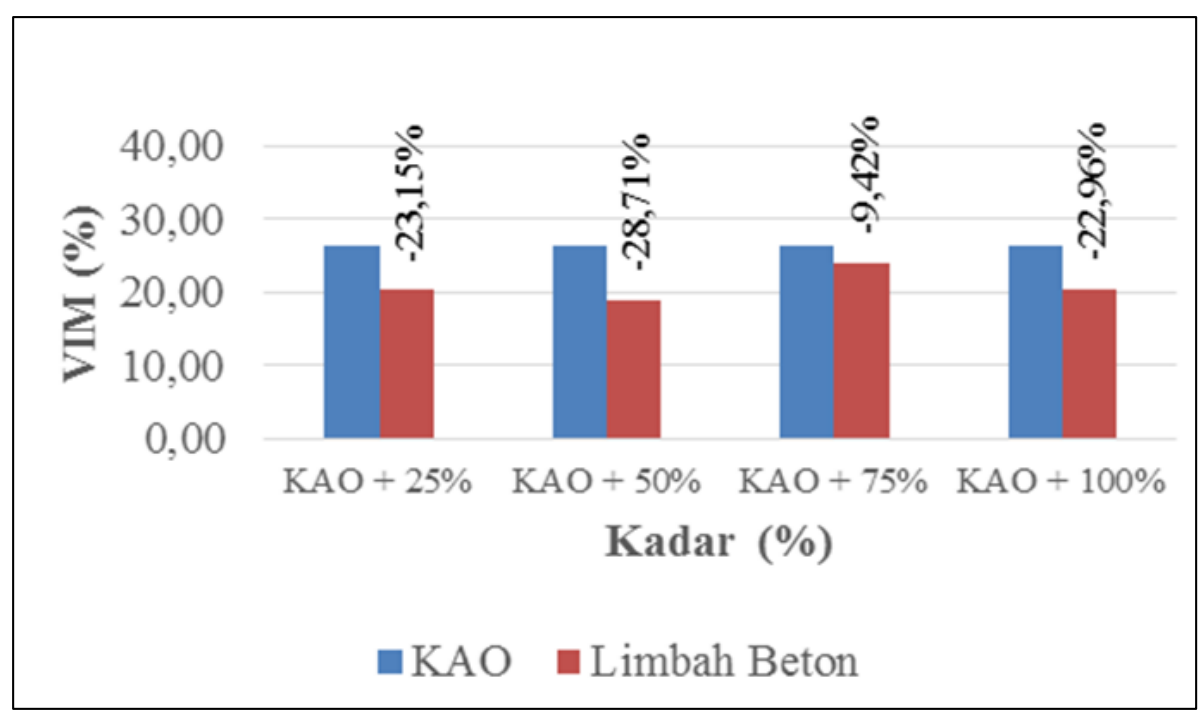

Gambar 1 Perbandingan VIM

Gambar 1 menunjukkan bahwa penggunaan limbah beton menurunkan nilai VIM benda uji. Pada benda uji dengan kadar limbah beton 25\%, VIM mengalami penurunan sebesar $23,15 \%$, pada benda uji dengan kadar limbah beton $50 \%$ mengalami penurunan sebesar $28,71 \%$, pada benda uji dengan kadar limbah beton $75 \%$ menurun sebesar $9,42 \%$, dan pada benda uji dengan kadar limbah beton $100 \%$ menurun sebesar 22,96\%.

Gambar 2 menunjukkan nilai VMA yang bervariasi pada benda-benda uji dengan berbagai kadar limbah beton. Benda uji dengan kadar limbah beton 25\% mengalami penurunan sebesar $0,73 \%$, benda uji dengan kadar limbah beton $50 \%$ mengalami kenaikan sebesar $1,81 \%$, benda uji dengan kadar limbah beton $75 \%$ mengalami kenaikan sebesar $33,16 \%$, dan benda uji dengan kadar limbah beton $100 \%$ naik sebesar $14,01 \%$. Secara umum benda uji yang menggunakan limbah beton mengalami peningkatkan VMA, kecuali pada benda uji dengan kadar limbah beton $25 \%$. 


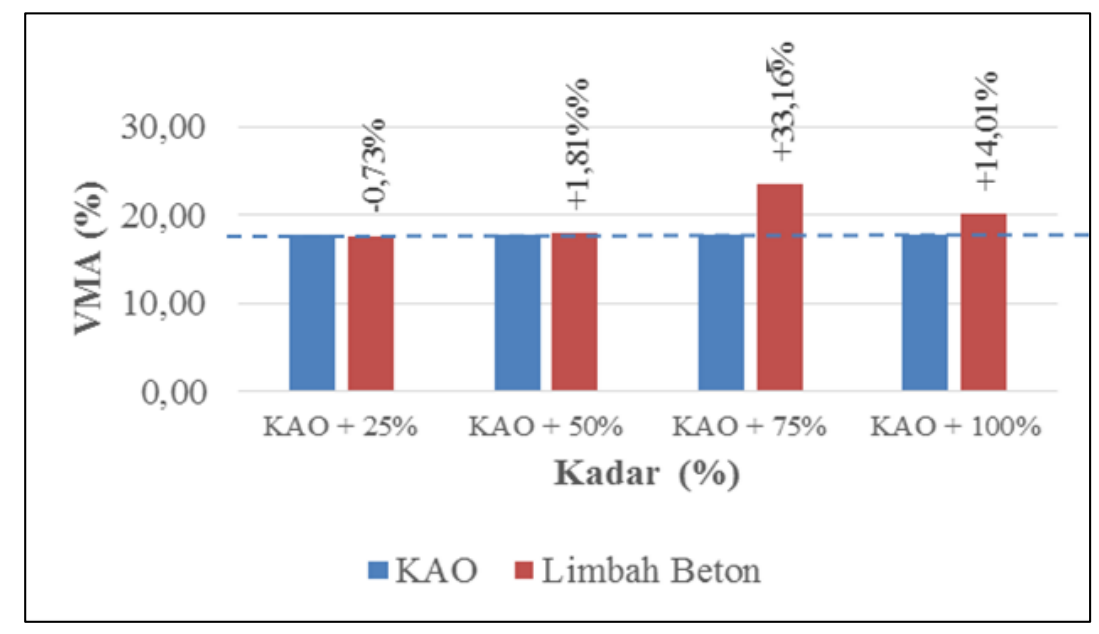

Gambar 2 Perbandingan VMA

Gambar 3 menunjukkan perbandingan stabilitas benda-benda uji yang menggunakan limbah beton dan benda uji yang tidak menggunakan limbah beton. Pada kadar limbah 25\%, stabilitas mengalami penurunan sebesar $5,43 \%$, pada kadar limbah $50 \%$ stabilitas naik sebesar $37 \%$, pada kadar limbah $75 \%$ stabilitas naik sebesar $15,19 \%$, dan pada kadar limbah $100 \%$ stabilitas naik sebesar $12,11 \%$. Peningkatan stabilitas terbesar terjadi pada benda uji dengan kadar limbah sebessar 50\%. Peningjatan stabilitas ini diduga disebabkan oleh sifat limbah beton yang memiliki nilai keausan yang tinggi.

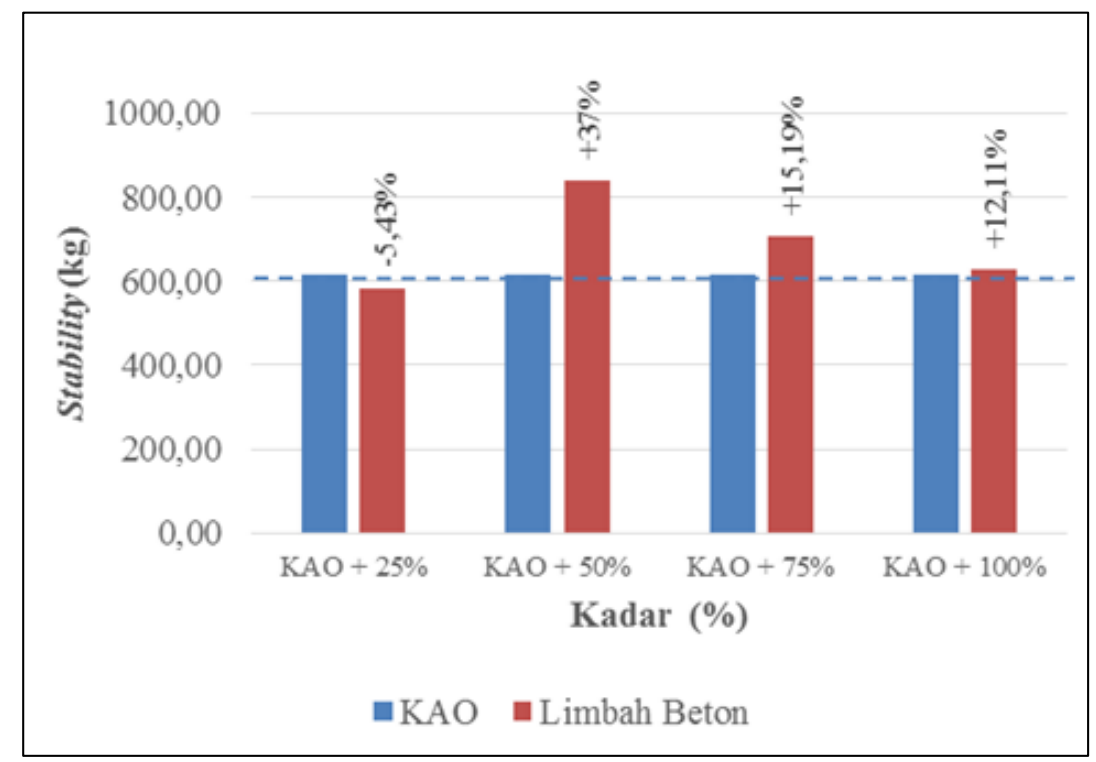

Gambar 3 Perbandingan Stabilitas

Gambar 4 menunjukkan nilai flow untuk masing-masing benda uji dengan kadar limbah beton yang bervariasi. Benda uji mengalami peningkatan flow pada kadar limbah antara 25\% hingga 75\%, sedangkan benda uji dengan kadar limbah 100\% mengalami penurunan flow. Untuk benda uji dengan kadar limbah 25\%, nilai flow mengalami kenaikan 
sebesar 5,58\%. Demikian juga untuk benda-benda uji dengan kadar limbah 50\% dan 75\%, yang mengalami peningkatan flow berturut-turut sebesar $11,55 \%$ dan $8,17 \%$. Sedangkan benda uji dengan kadar limbah 100\% mengalami penurunan flow sebesar 13,75\%.

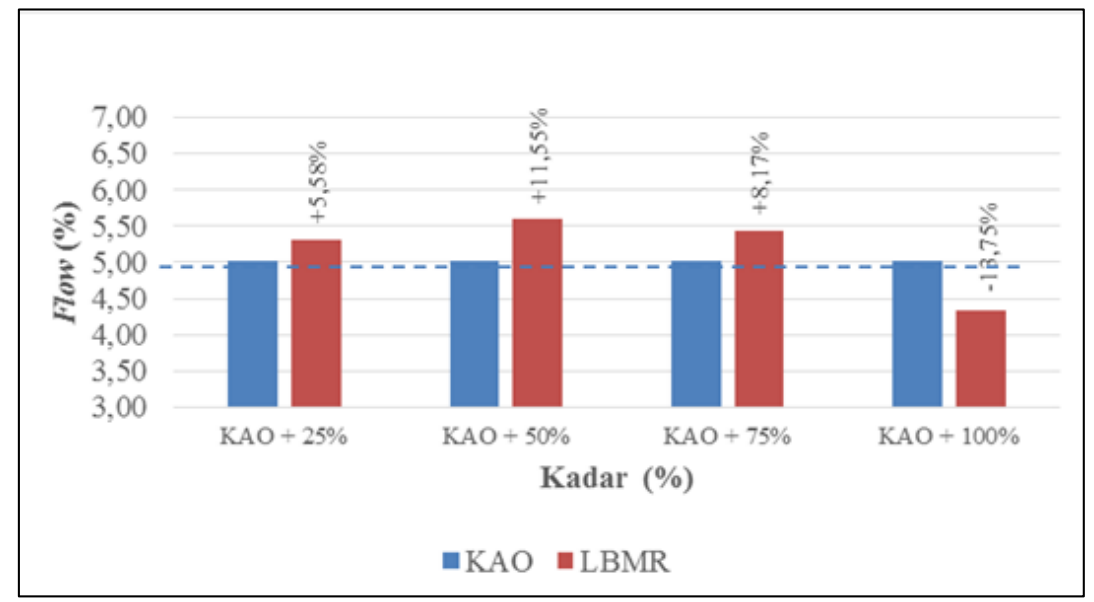

Gambar 4 Perbandingan Flow

Pada Gambar 5 ditunjukkan perbandingan nilai Marshall Quotient (MQ) benda-benda uji. Benda uji dengan kadar limbah 25\% mengalami penurunan MQ sebesar 10,31\%, sedangkan pada kadar-kadar limbah yang lain terjadi peningkatan MQ benda uji. Pada kadar limbah 50\%, 75\%, dan 100\%, MQ benda uji meningkat masing-masing sebesar $22,74 \%$, $6,56 \%$, dan $18,44 \%$ berturut-turut.

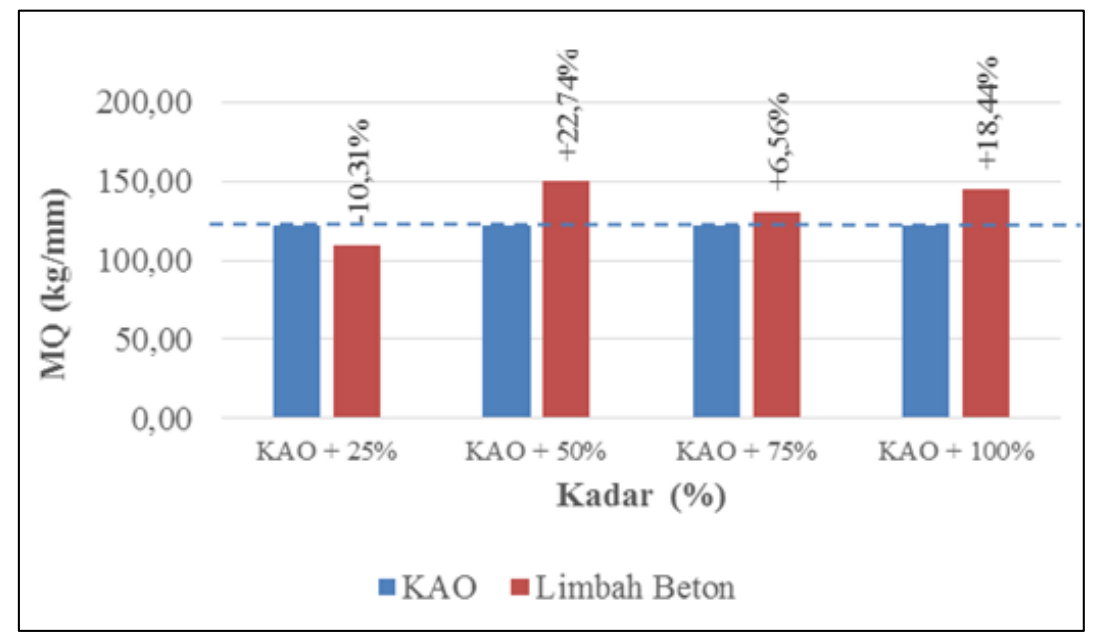

Gambar 5 Perbandingan MQ

\section{KESIMPULAN}

Berdasarkan penelitian terhadap campuran beraspal berpori dengan menggunakan limbah beton yang telah dilakukan, diperoleh beberapa kesimpulan sebagai berikut: 
1) Pemanfaatan limbah beton pada campuran beraspal berpori, dengan kadar limbah yang cukup besar, dapat meningkatkan nilai stabilitas campuran beraspal tersebut. Walaupun pada kadar limbah $25 \%$ nilai stabilitas turun sebesar 5,43\%, pada kadar limbah yang lebih tinggi stabilitas benda uji mengalami peningkatan. Peningkatan stabilitas benda uji dengan kadar limbah 50\%, 75\%, dan 100\% berturut-turut adalah 37\%, 15,19\%, dan $2,11 \%$.

2) Secara keseluruhan campuran beraspal berpori dengan menggunakan limbah beton mengalami peningkatan nilai VMA, kecuali untuk benda uji dengan kadar limbah $25 \%$. Penggunaan limbah beton dengan kadar 50\%, 75\%, dan $100 \%$ meningkatkan VMA berturut-turut sebesar 1,81\%, 33,16\%, dan 14,01\%. Hanya benda uji dengan kadar limbah $25 \%$ terjadi penurunan VMA sebesar $0,73 \%$.

3) Limbah beton menurunkan nilai VIM campuran beraspal berpori. Nilai VIM turun sebesar $23,15 \%$ untuk benda uji dengan kadar limbah 25\%, turun sebesar $28,71 \%$ untuk benda uji dengan kadar limbah 50\%, turun sebesar 9,42\% untuk benda uji dengan kadar limbah $75 \%$, dan turun sebesar 22,96\% untuk benda uji dengan kadar limbah $100 \%$.

4) Limbah beton meningkatkan flow campuran beraspal berpori. Benda uji dengan kadar limbah $25 \%$ mengalami peningkatan flow sebesar 5,58\%. Demikian pula utuk bendabenda uji dengan kadar limbah 50\% dan 75\%, yang mengalami peningkatan flow berturutturut sebesar $11,55 \%$ dan $8,17 \%$. Tetapi pada kadar limbah $100 \%$, flow benda uji turun sebesar $13,75 \%$.

5) Penggunaan limbah beton dengan kadar yang tinggi meningkatkan nilai MQ. Pada kadar limbah 50\%, MQ naik sebesar 22,74\%. Demikian pula untuk benda-benda uji dengan kadar limbah $75 \%$ dan $100 \%$, yang mengalami peningkatan MQ sebesar 6,56\% dan $18,44 \%$. Untuk benda uji dengan kadar limbah 25\%, MQ turun sebesar 10,31\%,

\section{UCAPAN TERIMA KASIH}

Ucapan terima kasih disampaikan kepada PT Subur Brothers yang telah memberikan sponsor dalam penyediaan agregat, aspal, serta fasilitas laboratorium untuk membantu penelitian ini.

\section{DAFTAR PUSTAKA}

Badan Standardisasi Nasional. 1990. Metode Pengujian Analisis Saringan Agregat Kasar dan Halus . SNI 03-1968-1990. Jakarta.

Badan Standardisasi Nasional. 1991. Metode Pengujian Kelekatan terhadap Aspal. SNI 032439-1991. Jakarta.

Badan Standardisasi Nasional. 2008. Metode Pengujian Berat Jenis dan Penyerapan Air Agregat Kasar. SNI 1969: 2008. Jakarta. 
Badan Standardisasi Nasional. 2008. Metode Pengujian Berat Jenis dan Penyerapan Air Agregat Halus. SNI 1970: 2008. Jakarta.

Badan Standardisasi Nasional. 2008. Metode Pengujian Keausan Agregat dengan Mesin Abrasi Los Angeles. SNI 2417: 2008. Jakarta.

Badan Standardisasi Nasional. 2011a. Cara Uji dan Penyelimutan dan Pengelupasan pada Campuran Agregat-Aspal. SNI 2439: 2011. Jakarta.

Badan Standardisasi Nasional. 2011b. Cara Uji Daktilitas Aspal. SNI 2432:2011. Jakarta.

Badan Standardisasi Nasional. 2011c. Cara Uji Titik Nyala dan Titik Bakar dengan Alat Cleveland Open Cup. SNI 2433: 2011. Jakarta.

Badan Standardisasi Nasional. 2011d. Cara Uji Titik Lembek dengan Alat Cincin dan Bola (Ring and Ball). SNI 2434: 2011. Jakarta.

Djumari, D. dan Sarwono, D. 2009. Perencanaan Gradasi Aspal Porus Menggunakan Material Lokal dengan Metode Pemampatan Kering. Media Teknik Sipil, 9 (1): 9-15.

Ramachandran, V.S., Paroli, R, M., Beaudoin, J.J., dan Delgado, A.H. 2002. Handbook of Thermal Analysis of Construction Materials. Norwich, NY: Noyes Publication.

Wagih, A.M., El-Karmoty, H.Z., Ebid, M., dan Okba, S.H. 2013. Recycled Construction and Demolition Concrete Waste as Aggregate for Structural Concrete. HBRC Journal, 9: 193-200. 